\title{
Effect of protein degradability on milk production of dairy ewes ${ }^{1}$
}

\author{
C. Mikolayunas-Sandrock, ${ }^{* 2}$ L. E. Armentano,† D. L. Thomas, ${ }^{*}$ and Y. M. Bergerł \\ *Department of Animal Sciences, and \\ †Department of Dairy Science, University of Wisconsin-Madison 53706 \\ $\ddagger$ Spooner Agricultural Research Station, University of Wisconsin-Madison, Spooner 54801
}

\section{ABSTRACT}

The objective of this experiment was to determine the effect of protein degradability of dairy sheep diets on milk yield and protein utilization across 2 levels of milk production. Three diets were formulated to provide similar energy concentrations and varying concentrations of rumen-degradable protein (RDP) and rumenundegradable protein (RUP): $12 \% \mathrm{RDP}$ and $4 \%$ RUP (12-4) included basal levels of RDP and RUP, $12 \%$ RDP and 6\% RUP (12-6) included additional RUP, and $14 \%$ RDP and 4\% RUP (14-4) included additional RDP. Diets were composed of alfalfa-timothy cubes, whole and ground corn, whole oats, dehulled soybean meal, and expeller soybean meal (SoyPlus, West Central, Ralston, IA). Estimates of RDP and RUP were based on the Small Ruminant Nutrition System model (2008) and feed and orts were analyzed for Cornell N fractions. Eighteen multiparous dairy ewes in midlactation were divided by milk yield (low and high) into 2 blocks of 9 ewes each and were randomly assigned within block (low and high) to 3 pens of 3 ewes each. Dietary treatments were arranged in a $3 \times 3$ Latin square within each block and applied to pens for 14-d periods. We hypothesized that pens consuming highRUP diets (12-6) would produce more milk and milk protein than the basal diet (12-4) and pens consuming high-RDP diets (14-4) would not produce more milk than the basal diet (12-4). Ewes in the high-milk-yield square consumed more dry matter and produced more milk, milk fat, and milk protein than ewes in the lowmilk-yield square. There was no effect of dietary treatment on dry matter intake. Across both levels of milk production, the $12-6$ diet increased milk yield by $14 \%$, increased milk fat yield by $14 \%$, and increased milk protein yield by $13 \%$ compared with the $14-4$ and $12-4$ diets. Gross N efficiency (milk protein N/intake protein

Received December 17, 2008.

Accepted May 14, 2009.

${ }^{1}$ This research was supported by the University of WisconsinMadison Agricultural Experiment Station/USDA/Hatch (Project \# 142-L190).

${ }^{2}$ Corresponding author: mikolayunas@wisc.edu
N) was 11 and $15 \%$ greater in the $12-6$ and $12-4$ diets, respectively, compared with the $14-4$ diet. Milk urea N concentration was greater in the 12-6 diet and tended to be greater in the 14-4 diet compared with the 12-4 diet, indicating that the excretion of urea $\mathrm{N}$ in this study was more closely related to dietary crude protein concentration than to protein degradability.

Key words: dairy sheep, protein degradability

\section{INTRODUCTION}

In ruminant diets, dietary protein is provided in the form of RDP and RUP. Sufficient RDP is essential to support the growth of rumen microbes, which may constitute 60 to $75 \%$ of the AA flow to the small intestine (Agricultural Research Council, 1980). Low RDP levels may compromise microbial growth, DM digestibility, and protein availability to the host. However, excess RDP that is not utilized for microbial growth is excreted in feces or deaminated to ammonia and excreted via urine and milk as urea (Clark et al., 1992; Castillo et al., 2001). Urinary urea contributes to environmental pollutants, such as atmospheric ammonia and nitrates in ground water (Tamminga, 1992). Excess RDP can also have negative consequences for the ruminant; excess RDP reduces embryo quality in sheep, possibly related to ovarian steroid concentrations affecting embryo development and transport (Berardinelli et al., 2001; Fahey et al., 2001).

Rumen-undegradable protein contributes to AA reaching the small intestine, increasing the flow of AA above the microbial AA supply. In dairy cattle, supplementing RUP in the form of expeller soybean meal increased the flow of nonammonia, nonmicrobial $\mathrm{N}$ to the small intestine and increased milk production by 7 (Cunningham et al., 1996) to 10\% (Broderick et al., 2002). Therefore, balancing ruminant diets for RDP and RUP may alter $\mathrm{N}$ utilization and increase milk yield. However, as suggested by previous authors (Santos et al., 1998; Reynal and Broderick, 2005), because of the interaction of RDP and RUP, evaluation of their effects on milk production must consider these nutrients independently. 
In dairy sheep, there are few studies on the effect of RDP and RUP on milk production and milk composition of high-producing ewes. Cannas et al. (1998) reported increased milk yield in response to increasing $\mathrm{CP}$ across 2 energy levels; however, the increased CP was mainly supplied by the Cornell protein fraction $\mathrm{B}_{2}$, with no indication whether this contributed to RDP or RUP. The reported effect of supplementing rumenprotected AA to dairy ewes suggests a potential benefit of postruminal AA supply. Sevi et al. (1998) found that rumen-protected Met $(+0.25 \%)$ and Lys $(+0.75 \%)$ increased milk yield, milk protein, milk fat, and gross efficiency of $\mathrm{N}$ utilization (milk $\mathrm{N}$ /dietary intake $\mathrm{N}$ ) in both moderate- (14\% CP) and high-CP (18.5\%) diets.

In sheep, there are dietary recommendations for RDP levels, but not for RUP. Recent guidelines (NRC, 2007) indicate that a $100-\mathrm{kg}$ dairy ewe producing 2.37 to $3.97 \mathrm{~kg}$ of milk/d requires $8.6 \% \mathrm{RDP}$ (\% of $\mathrm{DM}$ ) to maximize microbial protein production in the rumen. As RUP increases from 20 to $60 \%$ of $\mathrm{CP}$, dietary $\mathrm{CP}$ requirements decrease from 17 to $15.5 \%$ of $\mathrm{DM}$, indicating increased efficiency of $\mathrm{N}$ utilization with increasing RUP. This trial was conducted to estimate the effect of supplemental RDP and RUP on milk yield, milk composition, and protein utilization of low- and highproducing dairy ewes.

\section{MATERIALS AND METHODS}

\section{Ewes}

The trial was conducted at the Spooner Agricultural Research Station of the University of Wisconsin-Madison and all procedures were approved by the Animal Care and Use Committee of the College of Agricultural and Life Sciences. Eighteen third-lactation dairy ewes averaging 109 DIM (SD $=6 \mathrm{~d}$ ) were fed a mixture of the 3 experimental diets (Table 1 ) for $10 \mathrm{~d}$ before the beginning of the trial. At the evening milking of $\mathrm{d} 10$ and the morning milking of d 11, individual ewe milk yield was recorded, and 24-h milk yield was calculated. On the basis of this milk yield, ewes were divided into low- and high-milk-yield blocks (LM: $1.58 \pm 0.62 \mathrm{~kg} / \mathrm{d}$, $\mathrm{n}=9 ; \mathbf{H M}: 2.49 \pm 0.60 \mathrm{~kg} / \mathrm{d}, \mathrm{n}=9$, respectively) and randomly assigned within block to pens of 3 ewes each. Within each block, pens were randomly assigned to 1 of 3 dietary treatments. Dietary treatment sequences were balanced for carryover and applied to pens for 14 $\mathrm{d}$ in two $3 \times 3$ Latin squares. Ewes were milked twice per day (0530 and $1700 \mathrm{~h}$ ) and had access to water and a free-choice mineral-salt mixture. Ewes were weighed and body condition was scored daily during the final 4 $\mathrm{d}$ of each treatment period $(1=$ very thin, $5=$ very fat; Boundy, 1982).
Table 1. Composition of the diets (\% of diet DM) fed to lactating ewes

\begin{tabular}{|c|c|c|c|}
\hline \multirow[b]{2}{*}{ Item } & \multicolumn{3}{|c|}{ Diet $^{1}$} \\
\hline & $12-6$ & $14-4$ & $12-4$ \\
\hline \multicolumn{4}{|l|}{ Ingredient } \\
\hline Alfalfa-timothy hay, cubed & 54.3 & 59.7 & 62.5 \\
\hline Corn, whole & 5.7 & - & 3.1 \\
\hline Oats, whole & - & 4.5 & - \\
\hline Soybean meal, expeller ${ }^{2}$ & 4.3 & - & - \\
\hline \multicolumn{4}{|l|}{ Pellet } \\
\hline Beet pulp & 5.7 & - & 7.8 \\
\hline Corn, ground & 8.6 & 7.5 & 9.4 \\
\hline Soybean meal, dehulled & 5.7 & 16.4 & 9.4 \\
\hline Soyhulls & 5.7 & 11.9 & 7.8 \\
\hline Soybean meal, expeller & 10.0 & - & - \\
\hline
\end{tabular}

${ }^{1} 12-6=12 \% \mathrm{RDP}$ and $6 \% \mathrm{RUP} ; 14-4=14 \% \mathrm{RDP}$ and $4 \% \mathrm{RUP} ; 12-4$ $=12 \% \mathrm{RDP}$ and $4 \%$ RUP.

${ }^{2}$ SoyPLUS (West Central Soy, Ralston, IA).

Milk yield was measured during the final 4 milkings (2 d) of each treatment period using a graduated Waikato Goat Meter (Waikato Milking Systems NZ Ltd., Hamilton, New Zealand). Milk fat and protein percentages were determined on samples containing proportional amounts of morning and evening milk on the final 2 d of each period by using a CombiFoss 5000 instrument (Foss Electric, Hillerød, Denmark; AgSource Milk Labs, Menomonie, WI). Milk fat yield and protein yield were calculated for each ewe from daily milk yield and fat and protein percentages. A pen milk sample was compiled from proportional amounts of milk from each ewe and analyzed for MUN by using a Foss FT6000 instrument (Foss Electric; AgSource Milk Labs).

\section{Dietary Treatments}

Three dietary treatments were formulated to provide varying concentrations of RDP and RUP $-12 \%$ RDP and $6 \%$ RUP (12-6), 14\% RDP and 4\% RUP (14-4), $12 \%$ RDP and $4 \%$ RUP (12-4; \% of DM) - and similar $\mathrm{ME}(2.41,2.45$, and $2.39 \mathrm{Mcal} / \mathrm{kg}$, respectively). Diets were initially formulated based on NRC (2007), and protein degradability was evaluated based on in situ degradation in a dairy cow. After the trial was conducted, $\mathrm{N}$ fractions in feeds and orts were analyzed for the Cornell $\mathrm{N}$ fractions.

Diets contained alfalfa-timothy cubes (Ontario Dehy Inc., Goderich, Ontario, Canada) and concentrate pellets based on the feedstuff composition described by the NRC (2007). Expeller-pressed soybean meal (SoyPlus, West Central, Ralston, IA) was the feed ingredient chosen as the primary source of RUP for the diets. This plant source of RUP was chosen instead of an animal source because most dairy sheep production is 
Table 2. Chemical composition (\% of DM) of diet ingredients

\begin{tabular}{|c|c|c|c|c|c|c|c|c|c|c|c|c|c|}
\hline \multirow[b]{2}{*}{ Item } & \multirow[b]{2}{*}{$\mathrm{aNDF}^{1}$} & \multirow[b]{2}{*}{$\mathrm{ADF}$} & \multirow[b]{2}{*}{$\mathrm{CP}$} & \multirow[b]{2}{*}{ NFC } & \multirow[b]{2}{*}{ Ash } & \multirow{2}{*}{$\begin{array}{l}\text { Ether } \\
\text { extract }\end{array}$} & \multicolumn{5}{|c|}{ Protein fraction $^{2}$} & \multicolumn{2}{|c|}{$\begin{array}{c}\text { Protein } \\
\text { degradability }^{3}\end{array}$} \\
\hline & & & & & & & A & $\mathrm{B}_{1}$ & $\mathrm{~B}_{2}$ & $\mathrm{~B}_{3}$ & $\mathrm{C}$ & $\mathrm{RDP}$ & RUP \\
\hline Alfalfa-timothy hay, cubed & 47.2 & 31.3 & 15.3 & 31.4 & 10.2 & 1.6 & 3.1 & 1.2 & 8.2 & 2.0 & 0.9 & & \\
\hline Corn, whole & 11.7 & 4.1 & 9.5 & 75.4 & 1.2 & 3.7 & 0.2 & 0.8 & 0 & 0.9 & 0.4 & & \\
\hline Oats, whole & 30.7 & 13.6 & 11.9 & 51.6 & 2.3 & 4.4 & 1.6 & 2.1 & 7.5 & 0.3 & 0.4 & & \\
\hline $14-4^{6}$ & 22.8 & 15.2 & 29.1 & 42.4 & 4.9 & 2.3 & 1.9 & 4.7 & 21.0 & 0.8 & 0.5 & 12.3 & 7.6 \\
\hline $12-4^{7}$ & 22.7 & 15.3 & 22.3 & 49.5 & 4.9 & 1.9 & 2.3 & 1.5 & 17.1 & 0.8 & 0.5 & 10.6 & 6.6 \\
\hline
\end{tabular}

${ }^{1}$ aNDF $=$ amylase NDF.

${ }^{2}$ Protein fractions: $\mathrm{A}=\mathrm{NPN} ; \mathrm{B}_{1}=$ buffer-soluble true protein; $\mathrm{B}_{2}=$ buffer-insoluble protein; $\mathrm{B}_{3}=$ neutral detergent insoluble protein - acid detergent insoluble protein; $\mathrm{C}=$ acid detergent insoluble protein

${ }^{3}$ Based on the diet evaluation by the Small Ruminant Nutrition System (2008) model.

${ }^{4}$ SoyPlus (West Central Soy, Ralston, IA).

${ }^{5} 12 \%$ RDP and $6 \%$ RUP.

${ }^{6} 14 \%$ RDP and $4 \%$ RUP.

${ }^{7} 12 \% \mathrm{RDP}$ and $4 \%$ RUP.

located in countries where feeding animal by-products to livestock is not permitted.

After the 3 dietary pellets were created, protein degradability of the pellets and alfalfa-timothy cubes was estimated using an in situ degradation method in a dairy cow. Feeds were ground to pass through a 6-mm screen in a Wiley mill (Arthur H. Thomas, Philadelphia, PA), and 5-g samples were secured in Dacron polyester bags $(9 \times 15 \mathrm{~cm}, 52-\mu \mathrm{m}$ pore size $)$. Duplicate samples, including blanks, were suspended in a nylon laundry bag and soaked in water $\left(39^{\circ} \mathrm{C}\right)$ for 5 min before incubation. Samples were inserted in the ventral sac of the rumen and incubated for 0.5, 1, 2, 4, 8, 12, 24, and $48 \mathrm{~h}$. Time zero samples were soaked in water $\left(39^{\circ} \mathrm{C}\right)$ for $30 \mathrm{~min}$. After incubation, sample bags were rinsed in cold water in a commercial washing machine for 2 rinse cycles (15 min). Samples were dried overnight in a $60^{\circ} \mathrm{C}$ forced-air oven and percentage of $\mathrm{N}$ remaining was analyzed (Leco FP-2000 Nitrogen Analyzer, Leco Instruments Inc., St. Joseph, MI). The rate of protein degradation was estimated with a single-compartment exponential model: $\mathrm{y}=\mathrm{A}+\mathrm{B} \times\left(1-\mathrm{e}^{-\mathrm{kdt}}\right)$, where $\mathrm{y}$ is the $\mathrm{CP}$ disappearance at time $\mathrm{t}, \mathrm{A}$ is the rapidly digestible fraction (disappearance after a 30-min soak in water), $\mathrm{B}$ is the potentially digestible fraction (disappearance after a $48-\mathrm{h}$ incubation), $\mathrm{kd}$ is the fractional rate of digestion, and $\mathrm{t}$ is the incubation time $(\mathrm{h})$.

The $\mathrm{C}$ fraction was calculated based on $\mathrm{C}=1-\mathrm{A}-$ B. The RUP fraction was calculated based on RUP $=$ $\mathrm{C}+\left[\mathrm{B} \times\left(\mathrm{k}_{\mathrm{p}} / \mathrm{k}_{\mathrm{p}}+\mathrm{kd}\right)\right]$ using $\mathrm{k}_{\mathrm{p}}$ values of $0.051 \mathrm{~h}^{-1}$ for forages and $0.071 \mathrm{~h}^{-1}$ for grain (Small Ruminant Nutrition System, 2008). The RDP fraction was calculated as $\mathrm{RDP}=\mathrm{CP}-\mathrm{RUP}$.
After obtaining the results of the chemical composition of ingredients and protein degradability of the pellets and hay cubes, corn, oats, or SoyPLUS was added to the diets to obtain the desired levels of RDP and RUP. Based on the Small Ruminant Nutrition System (2008) model, the estimated concentrations of RDP and RUP actually offered by the $12-6,14-4$, and $12-4$ treatments were greater than the calculated diets (Table 2). If the Small Ruminant Nutrition System (2008) model estimations are correct, the diets offered provided 1.4 to 1.7 percentage units less RDP (average of 1.5 percentage units lower), 2.6 to 3.7 percentage units more RUP (average of 3.3 percentage units greater), and approximately 2.3 percentage units more total protein than the diets were designed to provide. However, the differences in percentages of RDP and RUP between the offered diets and the formulated diets were similar. The final composition of the diets is presented in Table 1 , and the chemical composition of the ingredients is presented in Table 2 .

Pens were fed ad libitum to allow $5 \%$ refusals. This low level of refusals was chosen because the physical form of the diets resulted in sorting among the pellet, grain, and cube components of the diets. The calculated percentage of RUP and RDP in the dietary treatments assumed consumption of the total diet, and with a low level of refusals, each pen was forced to consume as close to the total mixed diet as possible. Refusals were predominantly alfalfa-timothy cubes. During the final 4 d of each treatment period, orts were weighed, compiled by pen, and used to calculate pen intake.

Individual feeds and orts were sampled from each period. All samples were stored at $-20^{\circ} \mathrm{C}$ and ground 
to pass through a 1-mm screen in a Wiley mill before analysis. Dry matter was determined by drying samples overnight at $100^{\circ} \mathrm{C}$ in a forced-air oven. Amylase NDF (aNDF)was determined using sodium sulfite and $\alpha$-amylase (Sigma no. A3306, Sigma Chemical Co., St. Louis, MO) in an Ankom ${ }^{200}$ fiber analyzer (Ankom Technology, Macedon, NY) and was corrected for ash concentration according to Van Soest et al. (1991). Nonsequential ADF was determined using the method of Goering and Van Soest (1970), adapted for the Ankom ${ }^{200}$ instrument. Total $\mathrm{N}$ and Cornell N fractions were analyzed according to Licitra et al. (1996). Cornell $\mathrm{N}$ fractions include NPN (A), true protein with decreasing solubility $\left(\mathrm{B}_{1}, \mathrm{~B}_{2}, \mathrm{~B}_{3}\right)$, and $\mathrm{N}$ insoluble in acid detergent that is assumed to be indigestible (C). Ether extract was analyzed according to AOAC method 920.39 (AOAC, 1997; Dairyland Laboratories, Arcadia, WI). Nonfiber carbohydrates were calculated based on the equation $\mathrm{NFC}=100-\mathrm{CP}-\mathrm{aNDF}-$ ash - ether extract + neutral detergent insoluble CP.

\section{Statistical Analyses}

Data were analyzed as two $3 \times 3$ Latin squares, with pen as the experimental unit. Individual ewe measures of milk, fat, and protein yields; percentages of fat and protein; MUN; BW change from the previous period; and BCS at the end of the period were averaged by pen before statistical analysis. Intakes of diet DM, nutrient DM, and $\mathrm{N}$ efficiency (milk protein $\mathrm{N} /$ protein $\mathrm{N}$ intake) were measured by pen. Pen means and pen measurements were analyzed using the MIXED procedure of SAS (Version 9.1, SAS Institute Inc., Cary, NC). The model included square (i.e., milk production level), treatment, period $\times$ square, treatment $\times$ square, and the random effect of pen within square. Least squares means and standard errors of the mean are reported for each trait. Significant differences between least squares means were declared at $P<0.05$ unless otherwise noted, and tendencies were considered at 0.05 $<P<0.10$. Differences between least squares means were calculated using a Tukey-Kramer adjustment for multiple comparisons of means.

\section{RESULTS AND DISCUSSION}

For all traits, there was no statistically significant interaction of square $\times$ dietary treatment. Therefore, only least squares means for the main effect of milk production level and dietary treatment are reported.

\section{DM and Nutrient Intake}

The DMI and calculated nutrient intakes are presented in Table 3. The HM ewes consumed more $(P$
$<0.05) \mathrm{DM}$ and nutritional components than the LM ewes, suggesting that intake was regulated by energetic demands for milk production. The ability of dairy ewes to adjust their DMI to meet their energetic needs also has been reported by Cannas et al. (1998); ewes on low$\mathrm{NE}_{\mathrm{L}}$ diets increased DMI to achieve the same intake of $\mathrm{NE}_{\mathrm{L}}$ as ewes on high- $\mathrm{NE}_{\mathrm{L}}$ diets. There were no differences in DMI among protein degradability treatments. This result is similar to findings of earlier trials by others. Cannas et al. (1998) found no difference in DMI of midlactation ewes consuming diets with increasing CP percentages (14.2 to $21.2 \% \mathrm{CP}$ ) and across 2 energy levels. Furthermore, there was no difference in DMI of nonlactating ewes consuming diets with 3.2, 5.2, and $7.4 \%$ RUP $(8.8,10.9$, and $13.2 \%$ CP, respectively; Swanson et al., 2000) or wethers fed 4.3 and $6.4 \%$ RUP (12\% CP; Salisbury et al., 2004).

Neutral detergent fiber intake in the 12-6, 14-4, and $12-4$ treatments was 34,37 , and $37 \%$ of DMI, respectively, and was within the range of 28 to $38 \%$ recommended by Cannas (2002). Nonfiber carbohydrate intake was lower $(P<0.01)$ in the $14-4$ treatment compared with the $12-6$ and $12-4$ treatments. However, the concentration of $\mathrm{NE}_{\mathrm{L}}$ in the diet consumed, as calculated from the Small Ruminant Nutrition System (2008), was similar across milk production levels and dietary treatments (Table 3 ). These $\mathrm{NE}_{\mathrm{L}}$ values were within the range fed by Cannas et al. (1998) in an evaluation of high- and low-energy diets for dairy ewes (1.55 vs. $1.65 \mathrm{Mcal} / \mathrm{kg}$ ).

The CP concentrations of the consumed diets (20.6, 20.5 , and $17.8 \%$ of DM; Table 3) were greater than the formulated dietary CP levels $(18,18$, and $16 \%$, respectively), but the target difference in percentage of $\mathrm{CP}$ was achieved. Calculations of RDP and RUP consumed require knowledge of $\mathrm{k}_{\mathrm{p}}$, which is affected by the physical form of the feed. Because the diet was not a complete TMR, we have no reliable estimate of $k_{p}$ for feeds consumed and therefore no estimate of RDP and RUP. Analysis of the N fractions in feed consumed, measured by the difference in $\mathrm{N}$ fractions in feed offered and orts (Licitra et al., 1996), indicated the relative degradability of the intake protein (Table 3 ). The HM ewes consumed greater $(P<0.05)$ amounts of protein fractions $\mathrm{B}_{2}$ and $\mathrm{B}_{3}$ and tended to consume greater $(P$ $=0.0503)$ amounts of fraction A than LM ewes. Among dietary treatments, there were no significant differences in intake of the highly soluble protein fraction A. Ewes on the 14-4 treatment consumed more $(P<0.01)$ of the high-RDP fraction $\mathrm{B}_{1}$ than did ewes on the other 2 treatments. Intake of protein fraction $\mathrm{B}_{2}$ was lower $(P<0.01)$ in the $12-4$ treatment compared with the $12-6$ and 14-4 treatments. Ewes fed treatment $12-6$ consumed more $(P<0.01)$ of the $\mathrm{B}_{3}$ protein fraction, 
Table 3. Dry matter and nutrient intake of lactating dairy ewes

\begin{tabular}{|c|c|c|c|c|c|c|c|}
\hline Item & \multicolumn{3}{|c|}{ Milk production level } & \multicolumn{4}{|c|}{ Dietary treatment } \\
\hline \multicolumn{8}{|c|}{ Intake, $\mathrm{kg} /$ pen per day } \\
\hline $\mathrm{aNDF}^{6}$ & $3.07^{\mathrm{d}}$ & $3.87^{\mathrm{c}}$ & 0.16 & 3.33 & 3.54 & 3.53 & 0.12 \\
\hline $\mathrm{ADF}$ & $1.97^{\mathrm{d}}$ & $2.50^{\mathrm{c}}$ & 0.11 & 2.09 & 2.29 & 2.31 & 0.09 \\
\hline $\mathrm{NFC}$ & $3.24^{\mathrm{d}}$ & $4.02^{\mathrm{c}}$ & 0.17 & $3.82^{\mathrm{c}}$ & $3.40^{\mathrm{d}}$ & $3.71^{\mathrm{c}}$ & 0.12 \\
\hline $\mathrm{NE}_{\mathrm{L}}{ }^{7} \mathrm{Mcal} / \mathrm{kg}$ & 1.60 & 1.59 & & 1.62 & 1.57 & 1.60 & \\
\hline \multicolumn{8}{|l|}{ Protein fraction 8} \\
\hline A & 0.23 & 0.28 & 0.01 & 0.25 & 0.25 & 0.27 & 0.01 \\
\hline $\mathrm{B}_{1}$ & 0.16 & 0.19 & 0.01 & $0.14^{\mathrm{b}}$ & $0.25^{\mathrm{a}}$ & $0.13^{\mathrm{b}}$ & 0.01 \\
\hline $\mathrm{B}_{2}$ & $1.12^{\mathrm{d}}$ & $1.35^{\mathrm{c}}$ & 0.08 & $1.36^{\mathrm{c}}$ & $1.28^{\mathrm{cd}}$ & $1.06^{\mathrm{d}}$ & 0.10 \\
\hline $\mathrm{B}_{3}$ & $0.15^{\mathrm{d}}$ & $0.20^{\mathrm{c}}$ & 0.01 & $0.22^{\mathrm{a}}$ & $0.14^{\mathrm{b}}$ & $0.16^{\mathrm{b}}$ & 0.01 \\
\hline
\end{tabular}

${ }_{\mathrm{a}, \mathrm{b}}$ Means within an item and milk production or dietary treatment with different superscripts differ at $P<0.01$.

${ }^{\mathrm{c}, \mathrm{d}}$ Means within an item and milk production or dietary treatment with different superscripts differ at $P<0.05$.

${ }^{1}$ Low milk yield $(1.58 \pm 0.62 \mathrm{~kg} / \mathrm{d}$ at the beginning of the trial, $\mathrm{n}=9)$.

${ }^{2}$ High milk yield $(2.49 \pm 0.60 \mathrm{~kg} / \mathrm{d}$ at the beginning of the trial, $\mathrm{n}=9)$.

${ }^{3} 12 \%$ RDP, $6 \%$ RUP.

${ }^{4} 14 \%$ RDP, $4 \%$ RUP.

${ }^{5} 12 \%$ RDP, $4 \%$ RUP.

${ }^{6} \mathrm{aNDF}=$ amylase NDF.

${ }^{7}$ Based on diet evaluation by Small Ruminant Nutrition System (2008) model.

${ }^{8}$ Protein fractions: $\mathrm{A}=\mathrm{NPN} ; \mathrm{B}_{1}=$ buffer-soluble true protein; $\mathrm{B}_{2}=$ buffer-insoluble protein; $\mathrm{B}_{3}=$ neutral detergent insoluble protein - acid detergent insoluble protein; $\mathrm{C}=$ acid detergent insoluble protein.

which makes a greater contribution to RUP, than did ewes fed the other 2 treatments. There was no difference in the intake of protein fraction C. Based on these N analyses, the relative difference in protein degradability of the diets was achieved; the 12-6 diet supplied more RUP than the 14-4 and 12-4 diets, and the 14-4 diet supplied more RDP than the 12-6 and 12-4 diets.

\section{Milk Production and Composition}

The effects of initial milk production level and dietary treatment on lactation traits and BW and BCS are presented in Table 4 . The highest RUP diet (12-6) increased $(P<0.01)$ milk yield by $14 \%$ compared with the low-RUP diets (14-4 and $12-4 ; 2.05$ vs. 1.80 and $1.79 \mathrm{~kg} / \mathrm{d}$, respectively). The benefit of supplemental RUP in this trial is likely the increased flow of AA to the small intestine. Sevi et al. (1998) reported that rumen-protected Met and Lys increased milk yield in sheep. Fishmeal, an RUP source high in Met and Lys, increased milk yield in sheep by $17 \%$ compared with untreated soybean meal (Robinson et al., 1979). In this trial, RUP from expeller soybean meal, a protein source high in Lys but low in Met, also increased milk yield.

There was no effect of additional RDP (14-4 vs. 12-4) on milk yield (Table 4). All diets contained RDP levels above the $8.6 \%$ degraded intake protein requirement indicated by NRC (2007), and NFC levels were greater than the minimum $28 \%$ recommended by Cannas (2002). Because microbial growth should not have been limited, additional RDP provided by the 14-4 diet was likely excreted in feces and urine, providing no additional AA to the small intestine.

There was no significant effect of milk production level or dietary treatment on milk fat percentage. The HM ewes produced more $(P<0.01)$ milk fat than the LM ewes (Table 4). Compared with the 12-4 diet, supplemental RUP $(12-6)$ increased $(P=0.04)$ milk fat yield by $15 \%$. However, in the dairy cattle trials reporting a milk yield response to RUP, there was no effect of RUP on milk fat concentration or milk fat yield (Cunningham et al., 1996; Broderick et al., 2002). Compared with the 12-4 diet, supplemental RDP (14-4) also tended to increase $(P=0.08)$ milk fat yield.

There was no significant effect of milk production level or dietary treatment on milk protein percentage. The HM ewes produced more $(P<0.01)$ milk protein than the LM ewes. Compared with the 12-4 and 14-4 treatments, ewes consuming the $12-6$ diet produced 14 and $13 \%$ more $(P<0.01)$ milk protein, respectively. Previous authors have reported trends toward increased milk protein yield in response to RUP supplementation 
Table 4. Effect of initial milk production level and dietary treatment on production traits of dairy ewes

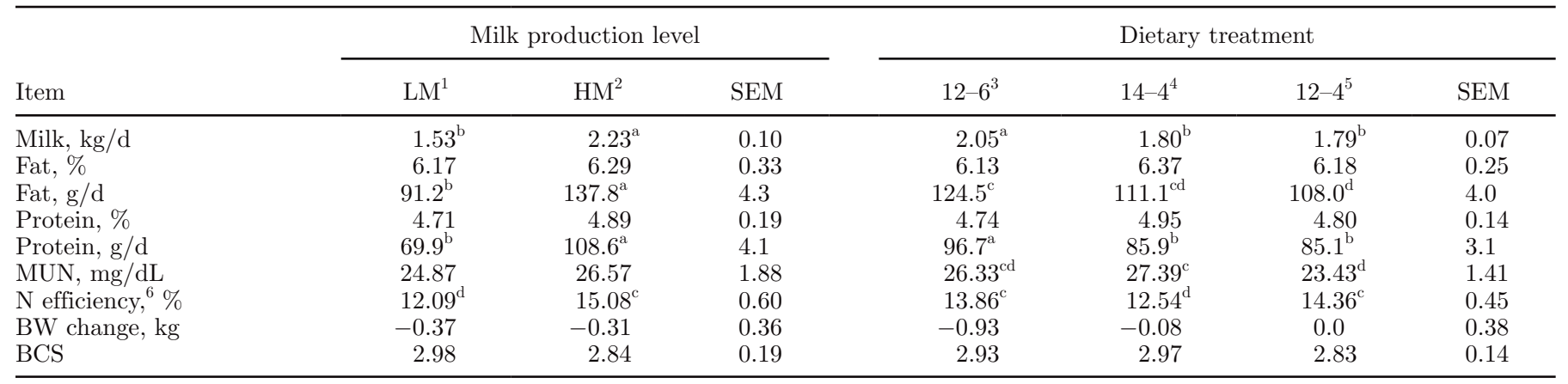

${ }^{\mathrm{a}, \mathrm{b}}$ Means within an item and milk production or dietary treatment with different superscripts differ at $P<0.01$.

${ }^{\mathrm{c}, \mathrm{d}}$ Means within an item and milk production or dietary treatment with different superscripts differ at $P<0.05$.

${ }^{1}$ Low milk yield $(1.58 \pm 0.62 \mathrm{~kg} / \mathrm{d}$ at the start of the trial, $\mathrm{n}=9)$.

${ }^{2}$ High milk yield $(2.49 \pm 0.60 \mathrm{~kg} / \mathrm{d}$ at the start of the trial, $\mathrm{n}=9)$.

${ }^{3} 12 \%$ RDP, $6 \%$ RUP.

${ }^{4} 14 \%$ RDP, $4 \%$ RUP.

${ }^{5} 12 \%$ RDP, $4 \%$ RUP.

${ }^{6}$ Calculated as milk $\mathrm{N} /$ feed $\mathrm{N}$, where milk $\mathrm{N}=(\mathrm{g}$ of milk protein/pen per day $) / 6.38$ and feed $\mathrm{N}=(\mathrm{g}$ of feed $\mathrm{CP} /$ pen per day $) / 6.25 \times 100$.

in sheep and cattle (Robinson et al., 1979; Broderick et al., 2002).

\section{N Efficiency}

Gross N efficiency was calculated as $100 \times($ milk $\mathrm{N} /$ feed $\mathrm{N}$ ), where milk $\mathrm{N}=$ ( $\mathrm{g}$ of milk protein/pen per day) $/ 6.38$ and feed $\mathrm{N}=$ ( $\mathrm{g}$ of feed $\mathrm{CP} /$ pen per day) $/ 6.25$. In this trial, $\mathrm{N}$ efficiency ranged from 12.09 to $15.08 \%$ (Table 4$)$. The HM ewes were $25 \%$ more $(P$ $=0.02$ ) efficient than the LM ewes at converting intake protein $\mathrm{N}$ to milk protein $\mathrm{N}$. The LM and HM ewes were similar in BW and had similar $\mathrm{N}$ maintenance requirements. Therefore, at similar levels of $\mathrm{N}$ intake, $\mathrm{HM}$ ewes had greater partial efficiency for milk production compared with LM ewes. Among dietary treatments, ewes consuming the 14-4 diet had 11 and $15 \%$ lower $(P<0.05) \mathrm{N}$ efficiency than ewes consuming the $12-6$ and $12-4$ diets, respectively. The $12-6$ and $12-4$ diets resulted in a similar $\mathrm{N}$ efficiency, but the $12-6$ diet produced more milk, milk fat, and milk protein compared with the 12-4 diet, supporting supplementation of RUP to increase milk yield per ewe.

In dairy cattle, reported gross $\mathrm{N}$ efficiencies range from 26.2 to $33.8 \%$ (Wattiaux and Karg, 2004). One reason for the lower $\mathrm{N}$ efficiency in this trial is that the efficiency of conversion of MP to milk protein is lower in sheep than in dairy cattle, 0.58 versus 0.67 (NRC, 2007). The intense genetic selection of dairy cattle for increased milk yield may have increased efficiency of $\mathrm{N}$ utilization of dairy cattle beyond the current genetic potential of dairy ewes. As an example, the $\mathrm{NE}_{\mathrm{L}}$ in dairy cattle may reach 4 times the $\mathrm{NE}_{\mathrm{M}}$, whereas the
$\mathrm{NE}_{\mathrm{L}}$ in dairy sheep is equal to the $\mathrm{NE}_{\mathrm{M}}$. At any rate, improvements in $\mathrm{N}$ efficiency of dairy flocks may be achieved by balancing diets for RDP and RUP and increasing milk yield.

\section{MUN}

Milk urea nitrogen levels have been used as an indicator of protein utilization in dairy cows (Jonker et al., 1998, 2002). In sheep, there is a strong relationship between BUN or MUN and urinary N (Kohn et al., 2005), suggesting that MUN also may be used in sheep to estimate the amount of excess $\mathrm{N}$ that is excreted. There was no significant difference in MUN attributable to milk production level. There was no difference between MUN levels of the high-CP diets (12-6 and 14-4). However, the MUN of the 12-4 treatment was lower $(P<0.05)$ than that of the $12-6$ treatment and tended $(P=0.053)$ to be lower than that of the $14-4$ treatment. These results suggest that milk urea levels in this study were more closely related to $\mathrm{CP}$ intake than to the degradability of the protein. Indeed, Swanson et al. (2000) reported increased serum urea-N levels with increasing RUP supplementation in sheep. Although the 12-6 diet resulted in the capture of more intake protein in milk protein compared with the 14-4 diet, the MUN data suggest that both of these treatments provided excess total dietary protein.

\section{$B W$ and $B C S$}

There was no effect of milk production level or dietary treatment on BW change or BCS (Table 4). Ewes 
were in midlactation (109 DIM) at the beginning of the trial and may not have been utilizing body reserves for milk production. The range of change in pen $\mathrm{BW}$ during the 14 -d treatment periods was -1.7 to +1.5 $\mathrm{kg}$, indicating that ewes were in relative neutral energy balance during the 42-d trial.

\section{CONCLUSIONS}

Supplementation of RUP increased milk, milk protein, and milk fat production in both HM and LM dairy ewes. This information is relevant to dairy sheep producers because the majority of sheep milk is processed into cheese, and protein and fat yields are important in determining cheese yield. Gross N efficiency, or the capture of intake protein in milk protein, was greater in the low-RDP diets. The excretion of urea, as indicated by MUN, was higher for ewes on high-CP diets compared with ewes on low-CP diets. For dairy sheep producers, the benefits of balancing RUP and RDP in lactation diets would be increased milk, milk protein, and milk fat yields and improved $\mathrm{N}$ utilization.

\section{REFERENCES}

Agricultural Research Council. 1980. The Nutrient Requirements of Ruminant Livestock. Commonwealth Agricultural Bureaux, Slough, UK.

AOAC. 1997. Official Methods of Analysis. 16th ed. Assoc. Off. Anal. Chem., Gaithersburg, MD.

Berardinelli, J. G., J. Weng, P. J. Burfening, and R. Adair. 2001. Effect of excess degradable intake protein on early embryonic development, ovarian steroids, and blood urea nitrogen on days $2,3,4$, and 5 of the estrous cycle in mature ewes. J. Anim. Sci. $79: 193-199$.

Boundy, T. 1982. Body condition scoring of sheep. Progr. Sheep Breeder :22-24.

Broderick, G. A., D. R. Mertens, and R. Simons. 2002. Efficacy of carbohydrate sources for milk production by cows fed diets based on alfalfa silage. J. Dairy Sci. 85:1767-1776.

Cannas, A. 2002. Feeding of lactating ewes. Pages 123-166 in Dairy Sheep Feeding and Nutrition. G. Pulina, ed. Avenue Media, Bologna, Italy.

Cannas, A., A. Pes, R. Mancuso, B. Vodret, and A. Nudda. 1998. Effect of dietary energy and protein concentration on the concentration of milk urea nitrogen in dairy ewes. J. Dairy Sci. 81:499-508.

Castillo, A. R., E. Kabreab, D. E. Beever, J. H. Barbi, J. D. Sutton, H. C. Kirby, and J. France. 2001. The effect of protein supplementation on nitrogen utilization in lactating dairy cows fed grass silage diets. J. Anim. Sci. 79:247-253.

Clark, J. H., T. H. Klusmeyer, and M. R. Cameron. 1992. Microbial protein synthesis and flows of nitrogen fractions to the duodenum of dairy cows. J. Dairy Sci. 75:2304-2323.
Cunningham, K. D., M. J. Cecava, T. R. Johnson, and P. A. Ludden. 1996. Influence of source and amount of dietary protein on milk yield by cows in early lactation. J. Dairy Sci. 79:620-630.

Fahey, J., M. P. Boland, and D. O'Callaghan. 2001. The effects of dietary urea on embryo development in superovulated donor ewes and on early embryo survival and development in recipient ewes. Anim. Sci. 72:395-400.

Goering, H. K., and P. J. Van Soest. 1970. Forage Fiber Analyses (Apparatus, Reagents, Procedures, and Some Applications). Agric. Handbook No. 379. ARS-USDA, Washington, DC.

Jonker, J. S., R. A. Kohn, and R. A. Erdman. 1998. Using milk urea nitrogen to predict nitrogen excretion and utilization efficiency in lactating dairy cows. J. Dairy Sci. 81:2681-2692.

Jonker, J. S., R. A. Kohn, and J. High. 2002. Use of milk urea nitrogen to improve dairy cow diets. J. Dairy Sci. 85:939-946.

Kohn, R. A., M. M. Dinneen, and E. Russek-Cohen. 2005. Using blood urea nitrogen to predict nitrogen excretion and efficiency of nitrogen utilization in cattle, sheep, goats, horses, pigs and rats. J. Anim. Sci. 83:879-889.

Licitra, G., T. M. Hernandez, and P. J. Van Soest. 1996. Standardization of procedures for nitrogen fractionation of ruminant feeds. Anim. Feed Sci. Technol. 57:347-358.

NRC. 2007. Nutrient Requirements of Small Ruminants. Natl. Acad. Press, Washington, DC.

Reynal, S. M., and G. A. Broderick. 2005. Effect of dietary level of rumen-degraded protein on production and nitrogen metabolism in lactating dairy cows. J. Dairy Sci. 88:4045-4064.

Robinson, J. J., I. McHattie, J. F. Calderon Cortes, and J. L. Thompson. 1979. Further studies on the response of lactating ewes to dietary protein. Anim. Prod. 29:257-269.

Salisbury, M. W., C. R. Krehbiel, T. T. Ross, C. L. Schultz, and L. L. Melton. 2004. Effects of supplemental protein type on intake, nitrogen balance, and site, and extent of digestion in whiteface wethers consuming low-quality grass hay. J. Anim. Sci. 82:35673576 .

Santos, F. A. P., J. E. P. Santos, C. B. Theurer, and J. T. Huber. 1998. Effects of rumen- undegradable protein on dairy cow performance: A 12-year literature review. J. Dairy Sci. 81:3182-3213.

Sevi, A., A. Muscio, L. Cordola, and D. Dantone. 1998. Milk yield of Comisana ewes fed rumen protected methionine and lysine at two levels of dietary protein content. Ital. J. Food Sci. 2:137-146.

Small Ruminant Nutrition System. 2008. Small Ruminant Nutrition System, Version 1.8.4. http://nutritionmodels.tamu.edu/srns.htm Accessed Aug. 28, 2008.

Swanson, K. C., J. S. Caton, D. A. Redner, V. I. Burke, and L. P. Reynolds. 2000. Influence of undegraded intake protein on intake, digestion, serum hormones and metabolites, and nitrogen balance in sheep. Small Rumin. Res. 35:225-233.

Tamminga, S. 1992. Nutrition management of dairy cows as a contribution to pollution control. J. Dairy Sci. 75:345-357.

Van Soest, P. J., J. B. Robertson, and B. A. Lewis. 1991. Methods for dietary fiber, neutral detergent fiber, and nonstarch polysaccharides in relation to animal nutrition. J. Dairy Sci. 74:3583-3597.

Wattiaux, M. A., and K. L. Karg. 2004. Protein level for alfalfa and corn silage-based diets: I. Lactational response and milk urea nitrogen. J. Dairy Sci. 87:3480-3491. 